\title{
Western "Supremacy" and the "Renaissance" Issue: Decolonising as Imitative Reaction
}

\author{
J. J. Ponti Venter \\ https://orcid.org/0000-0002-9144-2220 \\ North-West University \\ Ponti.Venter@nwu.ac.za
}

Abstract

Claude Levi-Strauss reminds us that "the notion of humanity, encompassing, without distinction of race or civilization, all forms of the human species, is a recent phenomenon and of limited expansion ... But for the major part of the human species, dozens of millennia, this notion appears totally absent. Humanity stops at the frontiers of the tribe, the language group, often even of the village ..." (Finkielkraut 1996, 1).

Keywords: Western “supremacy”; Renaissance; decolonising

Western "Rationality" and "Supremacy" versus African "Pristine" Origins: Introductory Background

Some two decades ago there was much talk about "the African Renaissance." And in South Africa, a term that already had a history elsewhere in Africa, "decolonising the mind" also became quite popular; the latter seems to have become dominant. Decolonising appears to be a mental liberation from "Western" (especially "white") "supremacy." But the Modern West had its own "liberation" struggles and it is the Modern West that gave birth to the ideas of "renaissance," "liberation," "revolution," and a search for historical origins and futures (made more acute by different evolutionistic philosophies).

What is today called "white" supremacy has had a very long growth and development, beginning with Ancient documented culture around the Mediterranean (some 10000 years ago), but which became acute with the growth of European imperialism and colonising of other nations worldwide, beginning with the Renaissance in the late 14th century.

The issues in mind are:

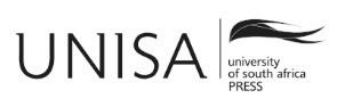




\section{Venter}

1. Why the contemporary reaction of people of especially African descent, against so-called "Western supremacy" or "white supremacy" by way of recovering primal (pre-colonial, pre-Christian) origins? This question will find a focus in an analysis of whether there has been, or still is, a Western hegemonic "supremacy" that could call up and warrant such a reaction (first article).

2. An in-depth analysis shows distinct similarities between decolonisation thought and Western "liberation" revolutions, especially group Messianism since the 18th century: a kind of substitution of the superiority (or at least equality) of the root culture of the formerly oppressed for that of the former (and even contemporary) oppressor. I shall try to clarify and critique this in the second article.

\section{"Renaissance"}

There is an irony in this new liberation movement. "Renaissance" and "mental liberation" are terms transferred from a reference to events, periods, and shifts in Western cultural and intellectual history and theorising to post-colonial cultural contexts.

"Renaissance" means "being reborn." It is not, however, the total renewal meant when one talks about "reborn Christians" in a New Testament sense; it is rather going back to the cultural "Eve's" lap: the European Renaissance that emerged in the late 14th century was Classicist; the Enlightenment emerging in the late 17th century was Neo-Classicist. In fact, under Modern Humanism, reality and history (as rooted in "nature" but transcending nature in "culture") became one: ontology has by and large been overlapping with philosophy of history (cf. Venter 1999). And here the meaning of "decolonising the mind" meets up with that of "Renaissance": mental liberation has taken on the meaning of a Ricoeur-type ideology: "back to my/our roots" (Ricoeur 1974).

Recovering African roots, even presenting them as superior, has become fashionable after former Western colonial powers had withdrawn. In South Africa, it has become a heated interaction, especially in the context of policies for "transformation" of schools and universities. Significant among black people (worldwide) is the return of a "Romantic, heroic, vitalism" (searching for Ancient heroes) with a strong sense of victimhood very similar to that in Europe before and after the French Revolution. One example (among many) can be found on You Tube where an Igbo Goddess, called Iruopa, is presented as the origin of the continental name, Europe. The rightful claims about the Moors dominating Southern Europe are often exaggerated to argue for a black Europe (Lisapo ya Kama n.d.). I have read on Facebook - a bit amazed - that King Moshoehoe I of the Basotho was a descendant of an Egyptian Pharao; even stranger the decolonising of type fonts to make them look like San-drawings (Afrikan Intelligence 2018; Campbell 2009). The University of Cape Town's recent identification with Saartjie Baartman is another. The impatience with works of art that appear as "counter- 


\section{Venter}

revolutionary" is very similar to the dominant attitudes of both Montagnards and Girondins during the French Revolution. As one reads the documents written by leading "decolonisers" and "transformers," one is surprised by the almost mirror image similarities with important leaders and writers in the 18th and 19th centuries, and then "right wing" authors (apart from the Marxist variants).

The appreciation of the pre-colonial (pristine) or indigenous roots has been two-sided. On the one hand there was a "liberal" or "conservative" Western appreciation in Western terms: the intention was to neutralise the Eurocentric parochial under-estimation of traditional cultures in, for example, the early 20th century anthropologist Sir J. G. Fraser's work. On the other hand, there has been the recovery of the original culture by black authors themselves (led by the Caribbeans) in: searching for the primal, the pristine ("repristination") and weighing this up against the Western hegemonic one; finding the pristine in fact superior to the Western. The pristine is more or less symbolic, spiritualistic, and accepts a life-style in magic; the Western one is supposed to be "rational" (based upon "scientific rationality" and "organisational-technical rationality").

\section{"Magic," "Rationality," and "Repristination"}

Western sociologists and anthropologists thus did not ignore the wish for a more appreciative review of "pristine" Africa. Some have attempted an upgrading of original, traditional culture by including "magic" into "rationality." A distinction into levels of rationality was made in an article by Jarvie and Agassi (1967) about the "rationality" of magic (Jarvie and Agassi 1967; 1970). Other participants were Peter Winch (1964), M. Hollis, and S. Lukes (1967; 1970): all trying to give a new appreciation of cultures in which "magic" plays a dominating role; trying to show some "rationality" in magical cultures (Winch 1964; 1970). What has been overlooked in this debate, is that the very idea of "rationality" is itself Western parochialism, and that "rationality" has always been a fluid idea.

The decolonisation thinkers from the former colonies and slave-holding countriesthose that would later support some kind of "African Renaissance"-have independently renewed their own history without taking rationality as their founding concept. The breeding ground has especially been the Caribbean, and initially it went unnoticed in many circles, because the works of authors such as Cabral, Cesaire, and Fanon were in French and it took some time before these reached into other language groups.

In a simplistic video on You Tube, the British African diaspora historian, Walker (2013), argues that the colonisers and slave owners made the histories of the indigenous peoples disappear and thus turned them into nobodies. One's "ancestral" history does not only provide possibilities for building "group" esteem and "self" esteem. The victim is thus dehumanised, depersonalised and the oppressor feels superior. Not having a history means not having achieved anything as a group, a tribe, a race. Although born 


\section{Venter}

in London, his early schooling was in Jamaica; his later studies in different institutions in the United Kingdom, but also in the Caribbean under Femi Biko and Kenny Bakie. Femi Biko (2000) is clear on the recovery of Ancient Africa: he believes Africans reject any distinction between "spirituality" (the personal inner side) and "religion" (the social, outer, expression) - two "dimensions of reality in an interdependent equilibrium." He argues that, in Ancient times, religion was the strongest integrative factor. Islam and Christianity are exclusivist and "paganism" (ancestor worship) is really the best option, and he attempts to show that pagan spirituality is good enough to integrate the scientific and technological culture; in fact, the roots of these are in Ancient times. Africa cannot advance without the decolonisation of its cultural capital.

Different forms of African traditional religion, mostly known as Voodoo, survived extensively in the Caribbean (even in Communist Cuba); the decimation of history has not been very successful (Clammer, 2104). Walker, Bakie and Biko draw their materials especially from West Africa and Egypt, but they do not give recognition to the fact that the uncovering of the history of those areas in fact came from Western research.

A crucial neglect by decolonisation authors is that recovering one's own history, also provides possibilities for criticism of own traditions and personal attitudes. When history is simply explained in terms of the binary of "victimhood" (from an "oppressor") versus ancient "heroic deeds" (against that "oppressor"), one easily falls into a new supremacy with regard to the oppressor. History will then be twisted to fit this binary and the most probable outcome will be to encourage the former oppressed to go for cultural hegemony in terms of Ancient traditions. This is what happened in Europe from the French Revolution onwards: I shall analyse it in the next article.

The brief discussion of "rationality" together with "magic" above makes sense as Western self-criticism too. As will appear below, Western rationality had to undergo a purification from "magic." Defoe recognises this; alchemy was alive and well up into early Modernity; Newton had a secret room in which he engaged in occult experiments and wrote an astrological interpretation of the Bible book of Daniel (Keynes 1946). Such ideas were also strong in Islam and in the Jewish Cabala.

"Rationality" had, since Tertullian, been the distinctive characteristic of the human being and rational action seen as humanly dignified action. Since quite early, Christian authors followed the indications of the Stoics: rationality indicated the human understanding of "divine law," also indicated all through the Middle Ages as "natural law," which included both the moral-social aspects of life and the disciplines which today will be categorised as "natural sciences." During the Middle Ages, the theological philosophers tended to view "science" in Greek terms - as deductive. Thomas Aquinas" Summa Theologia, in all its dryness and details, was the prime example of this. 


\section{Venter}

Somewhere, logical formalism had lost its connection with that "reason," which had been said to be distinctively human. ${ }^{1}$

\section{The Western Renaissance and the Origins of "Repristination"}

The Renaissance of the 14th to 16th century a.D. has usually been characterised or presented as "Classicist," i.e. a return to the Greek and Roman Classics, especially after Constantinople had fallen and Christian scholars in Ancient languages had fled to the West. This, of course, has been a misleading way of writing intellectual history. Modern authors have been showing an enmity towards Medieval Catholic scholarship, which was clearly rooted in a synthesis of the Classics with Christianity. The Reformers believed that the Classics had played too large a role.

\section{Classicism}

Not only had the scholars of the Middle Ages lost the connection with human life, but towards the 14th century the supreme Medieval power, the Roman Catholic Church, had become a corrupt, authoritarian, wealthy, power mongering institution. Internally, some (oppressed) reforming currents had emerged, such as the Mendicant Friars who used the vernacular. Studies of Ancient languages helped to clean the surfaces of the belief systems, and rediscover the coals under the ashes of a thousand years. The Arabs reintroduced Ancient Greek learning; it had been there all along, but in a Catholic garb. Some church members began to read the works themselves of those that the Catholic Church presented as authoritative (especially the later Augustine), and thus also gradually moved back to the Bible itself. Others followed the indications of Arab and Jewish scholars (gradually coming through since the 12th century) and thus landed in the direction of Rome and later Greece.

\section{Calvin and Slavery: From Humanist Classicism to New Testament understanding}

The scholarly language of those days was Latin; it is thus not surprising that the frustrations with inhumane abstract Catholic theological subtleness would firstly be countered with more pristine, humane, Roman philosophies, such as doctrines of "dignity" (dignitas) and "being-humanely-human" (humanitas).

With access to Ancient languages, more original texts were opened up. John Calvin (1509-1564) was not a theologian in the strict sense; he was actually a linguist trained firstly as a lawyer, then in church law and humanist moral philosophy, and he wrote a doctor's thesis on Seneca's De Clementia. He began his career as a Romanist, Humanist, Classicist. Up until the 19th century there had not been a clear distinction between

1 Deductivism and its concomitant quantification, or quasi quantification, has had this effect more than once. The earlier formats of Logical Positivism had no place for poetry, and the anti-utilitarians in France characterise economics as the most inhuman human science among disciplines (cf. Latouche 1995). One has but to read Bentham, Edgeworth and David Ricardo to see human agents being turned into calculating machine gears. 


\section{Venter}

church law and state law-Karl Marx still had to study church law as part of his law studies at university (Marx 1837). Calvin grew into the biblical text over time. His early studies of Stoicism, and later engagement with the biblical text, brought him to understand the dignity of the human being much better; he thus finally rejoiced in the growing insight that slavery is an abomination, apparently influencing Locke, via Puritanism and Hooker (and via Locke also Kant) (cf. Kant 1783; Kayayan 2013; Locke 1824, Second Treatise, 1-3).

\section{Neo-Platonist Humanism in Pico della Mirandola}

But also, Ancient pagan texts (from all kinds of religious and philosophical roots) soon became readily available. Most significant were the Neo-Platonist, Gnostic-like Hermetic and Cabbalist occult writings, studied and translated in the Academy of Florence. Well known, for example, is the De Dignitate Hominis of Giovanni Pico della Mirandola (1463-1494) - further analysis in Venter (2000). One particularly relevant aspect of these texts is exactly the mystical search for unification with Plato's "Ideal" world and beyond that the divine ekstasis of unification with the original One (Plotinus' fusion of the One in Plato's Parmenides with Aristotle's unmoved mover [Metaphysics, $\mathrm{XII}]$ ). And looking downward, the inclusion of the human being in the encompassing, the living macrocosm and its image, the state. But this had always been a vertical updown ontic movement; thus, the human soul was also bound into this vertical movement.

When Pico della Mirandola, denying a human essence, said that the human being can make itself, he meant: the dignity of the human is being in the Middle of the hierarchy, and he/she can choose either down the chain-of-being to become animal or plant; or upwards to become angelic or divine. It was still very far from Sartre's existentialist self-creating along the horizontal historical line. Following the argument of Finkielkraut about the incorporation of the Aristotelian hierarchy, Pico may have worsened elitist doctrine of intellectual supremacy. Finkielkraut argues that although the New Testament confesses to a singular humanity in Jesus Christ, the fusion of Christianity with the Greek hierarchy, in fact worsened the situation of some people within the earthly, social environment. Aristotle, followed by the Neo-Platonists, had thought of the universe as a hierarchy in which intellect is above senses and senses above matter, and on this basis believed that some humans (the less intellectual; slaves, women) are naturally inferior to the more intellectual (free citizens, males) (cf. Finkielkraut 1996, ch. 1). Roman Catholicism had, since Thomas Aquinas, clearly adopted this doctrine. ${ }^{2}$

Importantly, the basis for a horizontal, historical, mystical group development with an upwards gradient (the structure of the later secular faith in progress) had already been

2 This doctrine lasted into the 19th century-we find it in biology in the so-called "artificial classifications" and even after the French Revolution senior Catholics still maintained that this Aristotelian doctrine expressed the divine order of the biblical God (cf. Bi Joy G. Artificial Systems. Wikipedia: Great Chain). 
Venter

laid within Roman Catholic Christianity: some three centuries earlier in the thought of Joachim of Fiore (1135-1202).

\section{Group Messianism: Joachim of Fiore: Reading into the Past and the Future}

Among the many publications on Joachim, I find insightful those of Riedl $(2012 ; 2017)$ and Ziolo (2017). Relevant here is Joachim's historicising, horizontalising and collectivising of the Alexandrine patristic and Augustinian doctrine of a phased mystical pilgrimage.

The Augustinian mystical way had three phases:

1. Sense experiential hearing of God's word.

2. Rational application of this to the surrounding world, believing that the Bible was a strictly logical, rational book.

3. Intellectual intuition of the divine law (Augustine's interpretation of Plato's idea).

This, in the context of a struggle with the Neo-Platonist simplicity of the "One," here substituted with "God." There is a clear vertical elitism in this theory: once at the intellectual level, the mystic is in direct contact with the divine logos and law, and does not need the Bible anymore. In fact, Augustine calls ordinary believers stulti ("fools") who need the intellectuals as mediating teachers (this is the origin of the distinction between clerics and lays). ${ }^{3}$

But up to Joachim, the elite mystical cleric had always been an individual somewhere in a monastery, struggling with his/her need of intimate (vertical) contact with God versus his/her horizontal duty to care for the neighbour. Joachim adopted the Monastic elitism but changed the mystical way into group mysticism, viewing the history of humanity in terms of three epochs, correlated with the Augustinian revision of the Middle and Neo-Platonist view of the soul: sense, reason and intellectual intuition. He thus had the Old Testament as a (Jewish) sense-experience introduction to faith, ruled by the Father - this period lasted up to Calgary; the New Testament as a more-or-less rational (Christian) era ruled by the Son, lasting up to the 13th century; and a New Jerusalem under guidance of the Holy Spirit following upon this. Part of this was to be the millennium of peace:

The significance of his millenarianism is very substantial, for further reasons. He taught that the millennial kingdom of Revelation would come into being before the great final End-times ... This means that he invested millenarianism with a historicity, for the Millennium would be a real factor in world history, even if a short period of trials by the

3 Augustine began his expositions of the mystical way in early works such as De utilitate credendi (Augustine 1891). He later expanded this in De doctrina Christiana (Augustine n.d.) and adjusted his view of the human being to this especially in De trinitate books XII-XIV (Augustine 1955) (cf. Venter 1981). 


\section{Venter}

Antichrist precedes it. Secondly, he taught that the most virtuous monks would undertake to inaugurate the millennium kingdom as an earthly human reality.... This was an extraordinarily radical and new perspective on millenarianism ... "for Augustine the Apocalypse was primarily a guide toward an opening into heaven, but for Joachim it was the key to the meaning of human history." Joachim in effect implied that the kingdom would be inaugurated by people, and not by miraculous means. ... the new world order could be inaugurated by taking direct social-political action. (Anderson n.d.)

Modern Western thinkers adopted this idea of phased history, progressing from the senses (later subsumed under the "natural") to the rational-intellectual, and this through the efforts of human beings themselves: in some sense the Marxists are Joachimists. Within this framework a need was felt to determine the origin and end of human history (as the real cosmic history); later this would become part of secular repristination. Thus, a historical, mystical, group messianism became part of Western intellectual history. As secularism became anti-Christian, the "superior" pristine origins (primal ancestry) became part of the messianic tribalism that supposedly led progress. Joachim's followers already created suspicion when they tried to establish this New Jerusalem in a violent way.

In cases where the later "Platonists" did not follow a linear historiography, they returned to the Ancient and Medieval cyclical idea of the One as both origin and final end. But they did insert a phased history for the earthly part, allowing for the "spirit" to enter "nature" and emerge as "reason" (mature society). This has been part and parcel of NeoPlatonism, adopted by Pseudo-Scotus Eriugena, Meister Eckehart, Cusanus, and the Florentine Academy up to Hegel, Fichte, Goethe and Teilhard de Chardin. It was also stripped of its spirituality by Voltaire, Turgot, Kant and others. The re-emergence of "spirit" from "nature" could be indicated as "my" ancestral pristine tribal origin and advantage above other tribes.

These ideas would recur in many secular historiographies, influenced by different forms of Neo-Platonism, Alexandrine Patristics or Augustinianism: notably Vico, Rousseau, Lessing, Comte, Hegel, Goethe, Fichte, Nietzsche, Bertha von Suttner, up to Teilhard de Chardin, and indirectly in Turgot, Kant, Spencer, Darwin, Engels, Marx, Lukaçs. In many cases this philosophy of history would also be explained in terms of "youth," "adulthood" and "wise old age" of a society.

\section{Founding Totalitarianism: Platonist Repristination and the Macro-human State}

However, there was also a more direct form of Platonism, a Greek statism, as defended by Jean Bodin (1529-1596; Calvin's Roman Catholic contemporary) and later by Locke's older contemporary, Filmer.

Importantly, like Machiavelli in the Discorsi, Bodin wrote a Methodus ad Facilem Historiarum Cognitionem (1566): Renaissance authors were Classicist but by then the 


\section{Venter}

issue of scientific method had become acute; good historiography was needed for good repristination.

The metaphors and comparisons from Plato, used by Bodin, had a lasting effect on views of the state for centuries to come: a "microcosm" that shows the structure of the "macrocosm"; the "individual" more so the "family," therefore also the "clan" and "tribe" as "microcosmic." The state is the earthly "macrocosm" and is a larger, more important format of the household (Ch.1 [1]). ${ }^{4}$ This, clearly, is in the line of Plato's Politeia (cf. especially Book II). But it also follows Cicero's understanding of the state as an ordered structure of families and clans with a hierarchy of hereditary status (e.g. De Officiis, analysed in Venter 2000). Bodin refuses the utopianism of Plato and Thomas More; he believed the aim of the state is to make people happy in the sense of eudaimonia: Aristotle's superior contemplative life (I, ch. 1-2). The state, therefore, is led by family elites and is guided towards intellectual supremacy. This latter doctrine has always had the implication of a natural supremacy of the more intellectual above the more emotional.

Two further aspects of Bodin's views need special attention. Firstly, the idea of an absolute sovereign or the divine rights of the sovereign: it is above the law for it makes the laws. But it is bound by the contracts with the public it enters into. Surprisingly, Bodin inconsistently follows his Protestant contemporaries in requiring that the sovereign ought to be bound by the laws of nature and of God, but unlike the Calvinists he did not include checks and balances to ensure this is done. Secondly, he anticipates a later totalitarian doctrine that supported the root ideology: retro-projection and extrapolation into the future:

The law says that the people never die, but that after the lapse of a hundred or even a thousand years it is still the same people. The presumption is that although all individuals alive at any one moment will be dead a century later, the people are immortal by succession of persons ... (I, 2-3 [7])

Once this metaphor of the state as an "eternal" macro-person had taken hold, it could also be seen as an encompassing living being, in which the sovereign obtains a divine position (the "head"; the "brain"), and based upon which one could also recover the Ancient noble roots. This is the position variously taken by Hobbes, Rousseau and even Voltaire, and finally by Mussolini (par. II-III of 1933). Much is made today of "patriarchy" (even where normal fatherhood is discussed) but the real "patriarchy" (also in Filmer's so-called Biblical Patriarcha) is to accept a totalitarian state with the sovereign as Roman pater familias (cf. e.g. Voltaire 1750).

4 The internet text provides page numbers which I include between [...] 


\section{Venter}

\section{Repristination: To be Born Again-Machiavelli}

"Repristination" is a known occurrence in the context of "Renaissance": a rebirth to recover the "pristine" origins; a re-rooting to move forward from original purity. Prominent as pedagogic political historiographer here, was Machiavelli (1469-1527).

He propagated a "new method": comparing the socio-political events and structures of his own days with that of Classical Rome; of course, finding his own days wanting and the Ancient Roman republic the ideal state. While his work, The Prince, has become famous (or possibly infamous) for its argument that cruelty is the only way for a prince to govern effectively, his actual views are expressed in the Discourses, where he discusses the Republics of Sparta and Rome in terms of the doctrine of balance of powers. Using Plato and Aristotle's distinction of three good governance systems, monarchy, aristocracy and democracy, he finds a republic to balance elements of these three and thus to have endurance, rather than falling into the Aristotelian cycle of monarchy-tyranny-aristocracy-oligarchy-democracy-anarchy-monarchy ... Ancient Rome, for him, was the model for a lasting civil state and empire, especially because it became a sustainable fusion of the five ideas summarised below. Importantly, Machiavelli used a heroic, exemplarist, way of reading Livius, for the sake of contemporary praxis. This meant he read his issues back into Roman history. Important here, was reading back to the pristine founding of Rome. This presented him with a model for the structuring of a republic: the founder had to establish a unified constitutional state; implying that it had been necessary for Romulus to kill Remus (ends justifying the means) for this purpose. Repristination dialectically contained $R E$ novation (cf. Venter 2013).

This has been analysed in Venter, 2013, where I argued that such a return to "the good old days" is not possible, because what has happened over centuries or millennia, between the origin(al) and the present has already been absorbed into recent history. Machiavelli admired Roman imperialism, militarism, and republicanism, and blamed Roman Catholicism for sowing divisions or being to righteous. But factually, new weapons of war had been developed; this made it easier for separate republics and princedoms to survive and also for devious popes and cardinals to abuse their secular influence.

Machiavelli is particularly relevant for our topic: he bequeathed to Europe five ideas: that:

1. Wants (desires) are insatiable ("love" as biblical "agape" displaced by "competitive desire").

2. These wants are to be expressed in political expansion.

3. A totalitarian state must be in control of the minds (where Ancient blood shedding religions appear to be more apt to a military empire than Christianity). 


\section{Venter}

4. External warfare needs more and will produce more internal freedom of economic activity.

5. Powers have to be balanced for long-term civil stability.

Machiavelli (and his followers, Hobbes, Rousseau and Robespierre) were pagans at heart. In Machiavelli's case, the Roman Fortuna was always around to mess up human planning. ${ }^{5}$

Two other historical factors in the Renaissance need to be looked at: 1) the voyages of exploration to the Americas and India; and 2) the opening up of guild secrets of arts and crafts.

\section{Voyages of Exploration}

The well-known voyagers were Christopher Columbus (1441-1506) and Vasco da Gama (1460-1524). Both voyagers had double missions: spreading Christianity in its Roman Catholic form, and trade (and to protect these: starting settlements, colonies and military outposts). Clashes with Islamic traders in the Indian Ocean led to frequent wars along the East coast of Africa and towards India. Especially Latin America, this almost fusion of state with the Catholic Church, took the same form as in Southern Europe: conversion by the sword. The humanitas principle of the early Renaissance was dissipated between the rocks of economic expansion and forced subjection and conversions.

Finkielkraut analyses the Valladoid debate (1550-51) between Sepúlveda (1494-1573) and De la Casas (1484-1566). It was a debate to advise the Spanish king on colonial policy: the issue was the right to subject, colonise, enslave and coercively convert the indigenous people of the Americas, or rather to accept them as they are and work with them. Sepúlveda had "pristine" knowledge of Aristotle, although he had never visited any of the colonies, yet, following Aristotle, in spite of being a senior clerical scholar, he defended the Conquistadores on the basis of the "natural inferiority" of the "natives"; he considered them nearer to apes than to humans. De la Casas, who had done extensive mission work all over the Americas, took the opposite point of view: he saw dignified human beings, who fulfilled all conditions of being human, and he fought the destruction of their homelands, and thus, took a different approach to mission work, uplifting and conversion (Finkielkraut 1996, 14ff). The overlap between state and

5 But especially the Medici rulers and the Academy of Florence had spread pagan occultism all around and gave it space in Christianity, of course also giving the Inquisition more reason to search for "witchcraft". Especially astrology was integrated with "science": there are clear remnants of this in Renaissance Pythagoreanism such as Copernicus and John Dee, and still hidden even in Newton. 


\section{Venter}

especially the Roman Catholic Church, and its nasty effects, survived at least up to the reign of Napoleon Bonaparte. ${ }^{6}$

\section{The Guild Secrets Opened Up}

The second factor is the escape of arts and crafts from the claws of secrecy in the guilds. The advent of the printing press and the use of the vernacular broke down, not only the stranglehold of the Roman Catholic Church on confessional knowledge, but also of the guilds on the secrets of the crafts. But still, magic and technology were regarded as sisters. Leonardo da Vinci was in fact a craftsman working in a workshop, but his worldview was based upon Neo-Platonist occultism. The secrets of the workshop had come into the open: Biringuccio's (1959) work on fire techniques and metallurgy is one important example; Hooykaas (1972) mentions quite a number of such works. Eamon presents a whole, well-documented history of technology from Ancient times all through the Middle Ages up to the end of the Renaissance, in which he opens up the links between the Neo-Platonist occult world view with its revived Pythagoreanism giving magical meaning to number and space (still visible in Copernicus, Da Vinci, Michelangelo, Dee, Fludd, Bruno, Cusanus and many others). He also shows how Tommaso Campanella (1568-1639) had begun to show the progressive demystification of the mechanical arts, believing that as people came to know how machines work, the magical side may wear off, and (like Descartes later), that knowledge of mechanical laws could lead to mastery of nature.

Technological progress, both in terms of greater sophistication of techniques and wider application of them, was exceedingly rapid between the 14th and 17th centuries ... the output of writings on technology was larger than at any time previously, and by the beginning of the 17th century European intellectuals praised the new inventions that they believed had made Europe vastly superior to antiquity and to other cultures of the world. (Hooykaas 1972)

The connection, though watered down, between Ancient religions, magic and science did not simply disappear. Campanella was jailed by the Inquisition; he was suspected of being an occultist (like Giordano Bruno). It was absorbed into so many secret societies, temples, clubs and laboratories until deep into Modernity. Factually, the repristination to Ancient religious ideas became stronger in the 18th and 19th century, and in places (via Romanticism) became the basis for neo-pagan totalitarian ideologies. With urbanisation, mechanisation, concentration of production, better means of transport, increased world trade, events and changes in the life of the ordinary citizen came at an increased rate, and together with this a longing for a return to the quiet rural life in "nature."

6 Above the entrance of the Sacre Coeur in Paris built from 1875 to 1914, on the one side one has a mounted soldier with a sword and on the other side a mounted cleric with a cross. But in Guadalajara (Mexico) I have seen graffiti in a museum, that portrays the cleric as soldier and the long end of the cross as a sword. 


\section{Venter}

\section{Early Debates on Trade, Land and Economy}

Given the changes in lifestyle and production in Europe and the beginnings of settlements elsewhere, economic issues found their place in legislation, mathematics (calculation and bookkeeping), moral discussions, church life, and so forth. This, in documented history, has been a repeated pattern. With the growth of trade in North Africa the Egyptians had their own calculations: measuring land along the Nile and setting the rules of trade in the Sahara and around the Mediterranean. In the Hellenistic era, Lucianus, dramatist, satirises the Stoics' merciless calculations and imposition of compound interest (Lucianus II, Loeb, 448ff; 497ff).

From the 12th century onwards navigation tools had been improved; with the disclosure of techniques more concentrated production sites became available together with an urban middle class. The nobility also moved to the cities, leaving their feudal serfs, sojourners and tenant farmers to work the land while they remained in control. Many poorer rural people used the commons around urban areas to make a living, much like the communal farming in today's tribal areas in Africa.

Later, in different revolutionary eras, the tensions created would become (and still are) acute: individual versus social interest, hereditary power versus growing middle-class resentment, richer versus poorer, technology and science versus traditional culture, market versus control, uncontrolled competition versus equality, private fixed property and capital versus group solidarity.

People go out, buy and sell, see other techniques, other products, barter, bring back. Weber's thesis that Calvinism gave birth to capitalism, is Idealist, narrow, and ahistorical: it is true that in England and later in the United States the debate about trade and economics had been led by 17 th century Puritans, but these thinkers had divergences, and large capital investments had been much older. ${ }^{7}$

Notably, on the secular side (and Weber does not see this), already since the middle Renaissance (Machiavelli), a "natural-culture" tension began to grow and an implicit origin's ontology rooted in a more brutish, animalistic idea of "nature" had been emerging. This would in time, in econo-ontological terms, grow into the kind of "basesuperstructure" approach found in Capitalism and Marxism. But it is not present in Calvinism; the latter had a very strong sense of creation and divine law (even when they called it "natural law").

7 A fascinating book, that really opens up the circumstances of those times, is that of Bill Gilbert (n.d.), The Book. especially chapter 11 . The Weber thesis has been an "ideal type" that ill fits the events and growth of capital-intensive business within the context. Cf also B. Goudzwaard, De Culturele Oorsprong van het Kapitalisme. 


\section{Venter}

\section{Looking Back}

Many intellectual lines came together to produce what is now called "white supremacy" or "Eurocentrism." Classicism, as a reaction against Scholasticism, more and more became a repristination to Ancient pagan totalitarianism (reducing every aspect of human life to statism) and imperialism; the Machiavellian view of the greedy human being became widespread; the idea of a brutish natural origin became stronger. Voyages of exploration, intended for both missionary work and trade, became oppressive slavery and colonialism; the European knew it better. This was strengthened by the Joachimtype group Messianism, which would especially be revived in the advance to the revolutionary era. The fast development of natural science, technology (in the context of group mystical elitism), along with stories about the backwardness of other cultures, also fed into a sense of European supremacy. These points will be elaborated in the next section in order to provide a descriptive explanation of the strange reversal of colonialism among decolonisers.

\section{Early Modernity: Between Divine Law and Secular Supremacy}

"Modernity," as we today circumscribe it, did not suddenly arrive: there is always more continuity in history than meets the eye and quite often the cutting out of periods has a lot to do with our own prejudices. Using Descartes' (1596-1639) method of "universal doubt" as the "beginning" of Modernity is a very good example of this: "universal doubt" has its roots in Hellenistic scepticism, but had already been turned against itself by Augustine in the Contra Academicos (386 a.D.); Tommaso Campanella adopted this and Descartes twisted it into a rationalism.

Galilei (1564-1642) and Descartes (1596-1650) would give "science" a superior standing. It is in this secularist "superior standing" that we must see "Modernity," after some centuries of incubation, coming to full term birth.

\section{"Modernity": Supremacy in Science and Technology}

In Discours de la Méthode, it takes Descartes some pages to arrive at universal doubt. He firstly tells the story of his scholastic school years and what he rejected and retained from it. Rejection itself is also a form of historical continuity; reading his exposition of the deductive method, the reminiscences of Thomas Aquinas are very clear. It is probable that Campanella, whose works were edited in Paris in Descartes' young days, followed Augustine's refutation of Scepticism. Campanella also linked natural laws and technology. However, Descartes' methodical doubt was different: unlike Augustine and Campanella's belief that proving God's existence via universal doubt implies believing in "Goodness," Descartes simply wanted the trustworthiness of "subject-tive" reason proven.

The real contents of deductive arguments mostly appear towards the end, when hidden aims become clear: 


\section{Venter}

... but I have also observed certain laws established in nature by God in such a manner, and of which he has impressed on our minds such notions, that after we have reflected sufficiently upon these, we cannot doubt that they are accurately observed in all that exists or takes place in the world and farther, by considering the concatenation of these laws, it appears to me that I have discovered many truths more useful and more important than all I had before learned, or even had expected to learn [and] if God were now to create somewhere in the imaginary spaces matter sufficient to compose one, and were to agitate variously and confusedly the different parts of this matter, so that there resulted a chaos as disordered as the poets ever feigned, and after that did nothing more than lend his ordinary concurrence to nature, and allow her to act in accordance with the laws which he had established. ... Thereafter, I showed how the greatest part of the matter of this chaos must, in accordance with these laws, dispose and arrange itself in such a way as to present the appearance of heavens; how in the meantime some of its parts must compose an earth and some planets and comets, and others a sun and fixed stars. (DM, V §1-2 [14]

Where was Descartes headed? He was not yet a Kantian conceptualistic subjectivist: he believed that the laws of nature a priori in reason have also been "established" in nature by God, and that they provide useful truths. But he goes much further: he provides the first Modern deductive retro-projection ("imagined") to a cosmic origin. In time this ascribed role of God, bound by his own harsh laws, would be secularised away, too. The connection between "origin" (in nature), "law" and "destiny" is already suggested in this quote.

I believed that I could not keep them concealed without sinning grievously against the law by which we are bound to promote, as far as in us lies, the general good of mankind. For by them I perceived it to be possible to arrive at knowledge highly useful in life; ... to discover a practical, by means of which, knowing the force and action of fire, water, air, the stars, the heavens, and all the other bodies that surround us, as distinctly as we know the various crafts of our artisans, we might also apply them in the same way to all the uses to which they are adapted, and thus render ourselves the lords and possessors of nature. And this is a result to be desired, not only in order to the invention of an infinity of arts, by which we might be enabled to enjoy without any trouble the fruits of the earth, and all its comforts, but also and especially for the preservation of health, which is without doubt, of all the blessings of this life, the first and fundamental one; for the mind is so intimately dependent upon the condition and relation of the organs of the body, that if any means can ever be found to render men wiser and more ingenious than hitherto, I believe that it is in medicine they must be sought for. (DM VI §2 [21])

Reading the two quotes together we see a "natural history" of an emerging cosmos and a human reason rising above nature to ownership and control of "nature" using the mechanical laws and technical means even to finally bring "wisdom." Descartes had linked bodily substance and thinking substance much closer than the usual characterisation as a "dualist" readily allows for. Importantly, though his evolutionism: the consistency of natural laws (later known as "the principle of uniformity") that creates a cosmos out of chaos and the same consistency that, via human technology, can 


\section{Venter}

make humankind wise and (note the super-naturalistic homo deus): maîtres et possesseurs de la Nature ("masters" and "owners"). As Owens $(1987,65)$ characterises it: the master narrative which is a narrative of mastery.

During the Middle Ages the rational soul was considered the supreme part of "nature" and the laws of the intellect and morality as "natural" laws. We find the same idea of creaturely nature and divine law among the Puritans and Locke. But: Descartes reduced "natural" to "mechanical" and elevated "rational" to a divine position of control. Implicitly it was the seed of the economistic base-superstructure ontology of Capitalism and Marxism.

This was the real advent of Modernity: the projection to an origin, the uniformity of natural (sub-rational) laws, the emergence of rational, divine control. Kant almost literally expressed this in Was ist Aufklärung? (Kant 1783).

\section{Economic Rationality and Property: "Private Advantage, Public Benefits"}

This sense of technological advance, ownership and exact quantification had entered the idea of the rationality discourse. For example, a conception of law found among the merchant societies such as the lex mercatoria (1622) of Gerard Malynes:

So that [euerie extreame being vicious] Reason requireth a Law not too cruell in her Frownes, nor too partiall in her Fauors. Neither of these defects are incident to the LawMerchant, because the same doth properly consist of the Custome of Merchants in the course of Trafficke, and is approued by all Nations, according to the definition of Cicero, Vera Lex est recta Ratio, Natura congruens, diffusa in Omnes, Constans, Sempiterna "True law is a right reason of nature, agreeing therewith in all points, diffused and spread in all nations, consisting perpetually," whereby meum [mine] and tuum [yours] are distinguished and distributed by number, weight, and measure. [Introduction to the reader]

Malynes' work was aimed at understanding fair international trade: he thus gave ways of calculation and measuring time, but also tables of measures, weights, and exchange values, together with laws and fixed customs. Behind this is narrowing down of the ontology: a volun-tarist God governs all things by time and numbers, and humankind by weights and measures (Ch. III [19]).

We see a gradual shift in the idea of "reason," away from the Mediaeval, creaturely insight into divine law to guide human life, to a human-focused, welfare and advantageseeking focus. Malynes, however, is talking about a creaturely, practical reason: a flexible, normative, balance-seeking one. In 1656 Joseph Lee, a country pastor, argued that private advantage promotes the public good, defending the rights of improvement of land by enclosure of land (the "commons") (Taylor 1996). The Puritanist ethic of 


\section{Venter}

individual hard work that profits all, had taken root. But there were objections from another pastor, John Moore (1653). ${ }^{8}$

\section{Narratives, Missionary Work, Developing People, Religion, Human Rights (Defoe and Locke)}

Narratives of exploration and colonisation, and the different perspectives about these, so acutely expressed in the Valladoid debate, found literary expression in the famous works of Daniel Defoe (1660-1731), Robinson Crusoe (1719) and Moll Flanders (1722). Defoe, a Presbyterian, feels his way towards a belief in progress, but in a worldview religious sense. The explorers, missionaries, traders, and soldiers found different levels of knowledge, technology, literacy, in different areas of the world, and construed hierarchies of civilisation in which the West became both the summit and the standard.

Defoe was much humbler than the Cartesians. In his family catechism, The Family Instructor $(1715,2009)$ he focuses on home relationships (fathers and children, masters and servants, husbands and wives) as extended family in interaction (rather than "patriarchy"); and sets a model for children to thank God for having been created as a being with a rational soul, in the image of God, by which he knows the Creator of all, history past and future and also himself (cf. p. 6-8, First dialogue). In A System of Magick (Defoe 1728) a vague sense of progress through science comes to the fore: the real "magician" is not the occultist, but somebody who grows from philosophical practical wisdom to philosophy of nature (which includes natural science, technology and experiment) and finally reason: relating all things to God and honouring him (Ch. I [22-28], II [45-46]).

Together with John Locke and William of Orange, he had gone through all kinds of struggles regarding religious warfare and witch hunting, and he clearly states that whatever others are doing, he is not into hunting of heretics and occultists, for that way the killings and schisms will just increase (Ch. IV [124-5]). From this perspective one may understand the historical movement of the individual "models," Robinson Crusoe and Moll Flanders as pilgrimage of conversion from a sinful world of passion and desire to rational, peaceful stable God-fearing behaviour (Defoe 2009, Family Instructor ...). For him, it was a question of development and upgrading of the others, as Robinson Crusoe did on the island.

8 Although important, I cannot here enter into the specific debate about land and the "commons." For England, this debate is summarised in R. E. Prothero, 2013 (originally 1912). Notably, Rousseau saw enclosure of land as original sin (although now irreversible) while Hume apparently believed that the commons were abused and neglected exactly because nobody takes responsibility. Land and class made it into the theories of price and costs of Adam Smith and David Ricardo (cf. Taylor 1996, Chapter 6: Theories of Value). Presently a new so-called "Critical theory" (Neo-Marxism) also shows much interest in the issue of the "common", and so does the Post-Structuralist left, J. F. Lyotard (cf. Alexander Neumann 2015; Jean-François Lyotard 1977). 


\section{Venter}

John Locke (1632-1704) followed a line similar to that of Defoe; his parents were Puritans and he remained near the Dutch Remonstrants, but he also read Hooker (a semiCalvinist Anglican). Like Defoe, he fought for religious tolerance arguing that one cannot convert people by threatening to kill them; his three Letters on Toleration appeared from 1689 to 1692 (Locke 1824). He had a double (inconsistent) idea of rationality. In the Essay Concerning Humane Understanding (1690) he followed Descartes' mechanistic view of the body, reducing sensory knowledge to fragments extracted from time and space, thus rejecting Descartes' doctrine of innate ides. From the sensory fragments strict deductions are drawn and finally intra-mental archetypes, and (surprisingly) these are measured against divine law (especially Book IV, iii, ff). But in his Two Treatises of Government (1689) he had already opened the avenue for a kind of practical reason, going back to God's original creation, with an original insight in natural law (from Hooker) in the traditional Catholic sense. This is clear all through the First Treatise ... but condensed in the first 10 chapters of the Second Treatise. Another intensive Bible study, The Reasonableness of Christianity (1695), shows him to be part of the old rationality tradition going back to the Church Fathers (especially Augustine, Anselm, Thomas Aquinas).

Significantly, the First treatise ... is seldom read and analysed in secular circles; it is an exegesis of biblical texts against Sir Robert Filmer's Patriarcha, in which the divine right of the king as pater familias of the state is related to the creation of Adam. Filmer (1588-1653) assumed a totalitarian patriarchal state in line with the Catholic thinker, Jean Bodin (discussed below). Locke, with his refined knowledge of language, satirised his exegesis almost to the point of ridicule (cf. Filmer 1680).

Instead, he proposed an original state of rational freedom under natural law. One very influential summary passage from the Second treatise ... is worth quoting:

But though this be a state of liberty, yet it is not a state of licence ... The State of nature has a law of nature to govern it, which obliges every one: and reason, which is that law, teaches all mankind, who will but consult it, that being all equal and independent, no one ought to harm another his life, health, liberty, or possessions. For men being all the workmanship of one Omnipotent, and infinitely wise Maker; all the servants of one Sovereign Master, sent into the world by his order and about his business, they are his property, whose workmanship they are, made to last during his, not another's pleasure. And being furnished with like faculties, sharing all in one community of nature, there cannot be supposed any such subordination among us, that may authorize us to destroy one another, as if we were made for one another's uses, as the inferior ranks of creatures are for ours. Every one as he is bound to preserve himself and not to quit his station wilfully; so by the like reason when his own preservation comes not in competition, ought he, as much as he can to preserve the rest of mankind, and may not unless it be to do justice on an offender, take away, or impair the life, or what tends to the preservation of the life, the liberty, health, limb, or goods of another. (Bk II,ii,6) 


\section{Venter}

This is the origin of the Modern Western doctrine of human rights and dignity. Kant secularised this in a Cartesian and Hobbesian sense: competitive nature awakens in the human being, originally a brute, the faculty of reason which elevates the human being to a supernatural (divine) equality with all other rational beings: the ontological basis of the categorical imperative. The French "liberty, equality, brotherhood" all have their origin in these few lines, and it is also Modernised (Calvinist) rejection of slavery (although Locke was inconsistent in his application of this). The Protestants had thus linked up or even promoted a subtle shift of rationality and natural law from a controlling law to a liberating individualist one; Locke views the individual human being as God's independent, free, “property" by virtue of being God's creation. Locke's viewpoints were not simply an attack on Filmer, he also undermined another totalitarian, a social Cartesian named Hobbes.

\section{Hobbes and "the Reason of State" and Utilitarian Dignity}

Hobbes (1588-1679) ${ }^{9}$ was a Machiavellian Cartesian. He was probably the first Modern thinker (after Machiavelli) who reduced all inter-individual relationships to the subrational level of lust for power, glory and money. This, of course, was a suicidal social vision; no human race can survive a war of all against all. As a post-Renaissance thinker, he replaced the power of the church - a vicious threat according to him- -with the power of the state to moderate the vicious naturalistic ways of the individuals. He used the Cartesian mechanistic view of "nature" to design a strict deductive argument for the existence of the state: the greedy war of all against all necessitates social contracts for a peaceful life and defence against those beyond the contract. The natural human being functions like parts in a clockwork. But the running clock is the rational, peaceful, entity: thus, the state acquires a personality: ${ }^{10}$ it is Filmer's macro-human, consisting of micro-humans. Individuals may be rational in some quiet moments.

The state is the fierce Leviathan, the earthly God. The state is the very same as the kingdom of God on earth. Resistance against the sovereign (civil war) is the worst offense thinkable. The state has to moderate the natural striving of the individual, otherwise we shall fall back into the natural state of brutishness. But the outcome of this nature-socio-cultural dialectics is the total commodification and objectification of the citizen:

The power of a man, to take it universally, is his present means to obtain some future apparent good, and is either original or instrumental. ... The value or worth of a man is, as of all other things, his price; that is to say, so much as would be given for the use of

9 The following is an analytical summary of what I have previously written about Hobbes: Venter, JJ. 2001. Early modern conceptions of "natural law": Venter, 2001; 1999, 1996; 1997. Much of the above and in these articles have been based on Man and Citizen: De Homine and De Cive. Doubleday, 1972.

10 Hobbes characterises the state as persona ficta - a fictitious person like the Ancient mask-wearing actors in dramas. However, such metaphors have to be interpreted in the way of William James's theory of meaning: the "cash value" or the "netto effect" is important here: the metaphor in practice becomes literal; the state acts as a real personality above persons (cf. Venter 1997). 


\section{Venter}

his power, and therefore is not absolute, but a thing dependent on the need and judgement of another. An able conductor of soldiers is of great price in time of war present or imminent, but in peace not so. A learned and uncorrupt judge is much worth in time of peace, but not so much in war. (Leviathan, II, 10)

This is the very opposite of Locke's idea of human dignity; he rejected the commodifying and instrumentalising of God's very own property, the human being. Hobbes did accept a vicious equality: we are all equally able to annihilate one another. Locke propagated equally in God's hands and, therefore, took the power over one another out of our hands. Thus, Locke had some appreciation of non-state relationships of authority, such as that of a father in his home; Hobbes understood these all as but organs-and-members of the Leviathan. One needs the opposition between Hobbes and Locke in order to understand what followed in the next two centuries.

\section{Different Lines Coming Together}

Towards the end of the 17th century the sense of progress became stronger; as shown above in Defoe. Today's Marxist egalitarians may hide it, but Marx and Engels were fully committed to the faith in progress (and therefore also that some humans are/were savages near to being apes). The foundations, however, had already been laid in the group Messianism of Joachim of Fiore and his followers; this would sink to the bottom of the historical stream to surface again in the early 19th century (Hegel, Fichte). The sense of Western superiority in terms of science and technology had been strong at the end of the Renaissance, and the claims of Descartes about human mastery were decisive.

Descartes hesitatingly set forth a perspective for centuries to come: the uniformity of natural laws could produce a creaturely universe independently: the first version of a big bang like evolutionistic perspective, which would undergird the faith in progress. The Cartesian mechanistic view of natural law, however, would create a particular understanding of the social environment: from the Machiavellian repristination to the Ancient eroos-eris motive with the idea of insatiable greed, Hobbes would derive a social structure which would thence be in the competitive dialectics of individual (brutality) versus social-cultural peace and rationality. In Hobbes, this had not yet developed into a historical succession of progress from nature to culture: this would come soon after in Vico, Turgot, Voltaire and Kant.

The Cartesian view of natural law was not the only one, however. In Calvin, Defoe, Locke, and later in the Physiocrat Quesnay (and in some sense even in August Comte), the older, Medieval view of natural law as rational law survived, with a much more biblical view of human relationships. However, its meaning had become more liberal rather than controlling, and it was soon brought into one system with the Cartesian view: Vico, the first to really advance a theoretically construed faith in inevitable progress towards rationality, assumed both a (Cartesian) physicalist natural law and a social natural law - these two interacting with one another. 


\section{Venter}

The Platonist personification of society from Bodin over Filmer to Hobbes, together with the Aristotelian vertical hierarchy, laid the basis for the soon to come horizontal upwards gradient in a historicised ontology climbing from nature to culture, ending in a supernatural control situation. This horizontalising of the ontology brought with it a new search backwards to some faraway ("mythical") origins, but also future expectations of rational culture led by an elite: different kinds of group consciousness and group messianisms with leader cults. In the present proponents of decolonisation, the recovering of Ancient roots (repristination) is quite distinctive: it presents itself as a-moving-to-the-future on the basis of pre-colonial and pre-Christian roots.

From the mish-mash of Renaissance tendencies some crystallisation became evident in early Modernity - a stronger sense of history and method, with retro-projections of present ideals or strivings into an original past. This could be from a more Christian side (Defoe, Locke) or a more secular side (Descartes' evolutionism) or even a "semi-pagan" side (Machiavelli; Hobbes). The biblical idea of creation remained below the surface, but the Modern idea of human rationality being rooted in the sub-rational, and that the sub-rational is the root of evil but also of progress through trials, had a very ambiguous outcome: for explicit Christians from Defoe over Locke up to Husserl, the way of redemption became a way of extraction from the sub-rational; a reverse to "natural law" or original rationality. For secularists, a parallel process had been developed: the purification of reason, from the sub-rational, which, over time became a faith in automatic progress from "nature" to super-natural "rationality"-I dare say Kant's Critiques had to be entitled: Critiques for the purification of reason. Of course, this turned the whole repristination project upside down: the heroic origin was not rational: in the cases of Voltaire, Kant, Hegel, Fichte it had to be saved by the assumption of "panto-deism"-inserting the distant rational god into the stream of nature.

\section{References}

Afrikan Intelligence, 2018. Europe was Named after an Igbo Princess; Europe is Black. https://www.youtube.com/watch?v=UNS9unkWiFQ.

Anderson, A. (n.d.) "Joachim of Fiore: Social Upheaval from Biblical Prophecies. The Socialhistorical Significance of his Visionary Millenarianism.” This e-booklet, estimated from dates in the references, has been published after 1997. Accessed August 20, 2019. www.rudolfsteinerstudies.com.

https://pdfs.semanticscholar.org/5b0b/e17d9263b2d17087052fb0d2bff7e91fddcf.pdf.

Augustine. (n.d.) De doctrina Christiana. Opera omnia, Patrologiae latinae, tomus 44, a curante J. P. Migne, Turnholti. Brepols.

Augustine. 1891. De utilitate credendi. Recensuit I. Zycha. Pragae/Vindobonae/Lipsiae: Tempsky/ Freitag. Corpus Scriptorum Ecclesiasticorum Latinorum 25 (25): pars I.

Augustine. 1955. La trinité (De trinitate). Paris, Desclée de Brouwer, 1955. Tome 15: Livres IVII. Tome 16: Livres VIII-XV. 


\section{Venter}

Bi Joy, G. (n.d.) “Artificial System of Plant Classification, Taxonomy, Botany.”

http://www.biologydiscussion.com/plant-taxonomy/plant-classification/artificial-systemof-plant-classification-taxonomy-botany/77655.

Biko, F. 2000. "New African. Software Problems in the African Renaissance Process." https://www.questia.com/magazine/1G1-68767986/software-problems-in-the-africanrenaissance-process.

Biringuccio, Vannochio. 1959(1540). De la pirotechnia. Dover Books on Earth Sciences: Dover Classics of Science and Mathematics, translated by Cyril Stanley Smith; Martha Teach Gnudi. Courier Dover Publications, 477.

Campbell, K. 2009. "Negating the Serif: Post-colonial Approaches to Typeface Design." https://www.defsa.org.za/sites/default/files/downloads/2009conference/Campbell.pdf.

Clammer, P. 2014. "Understanding vodou in the Caribbean.” November 2014. https://www.lonelyplanet.com/caribbean/travel-tips-and-articles/understanding-vodou-inthe-caribbean/40625c8c-8a11-5710-a052-1479d2766bb7.

Defoe, Daniel. 1728. "A System of Magic; or a History of the Black Art: Being an Historical Account of Mankind's most early Dealing with the Devil; and how the Acquaintance on both sides first Begun." https://quod.lib.umich.edu/e/ecco/004843566.0001.000?view=toc.

Defoe, Daniel. 2009. "The Family Instructor: In Three Parts; I Relating to Fathers and Children; II to Masters and Servants; III to Husbands and Wives." Michigan: University of Michigan Library.http://name.umdl.umich.edu/004844748.0001.001.

Filmer, Robert (Sir). 1680. Patriarcha: Or the Natural Power of Kings by the Learned Sir Robert Filmer. London: Walter Davis.

Finkielkraut, A. 1996. L'humanité perdue; Essai sur le XXe siècle. Ed. de Seuil.

Gilbert, Bill. (n.d.) “The Book. Edwyna Condon Gilbert,” edited by William. http://vlib.iue.it/carrie/texts/carrie_books/gilbert/00acknowledgements.html; especially chapter 11.

Hobbes, T. Leviathan. 1999. "Renascence Editions.” http://www.luminarium.org/renascenceeditions/hobbes/leviathan.html.

Hooykaas, R. 1972. "Religion and the Rise of Modern Science.” Grand Rapids. Eerdmans Publishing \& William B. Regent College Publishing (October 1, 2000). https://wwwhistory.mcs.st-andrews.ac.uk/Extras/Keynes_Newton.html; https://www-history.mcs.stand.ac.uk/Extras/Keynes_Newton.html. 


\section{Venter}

Jarvie, I. C., and J. Agassi. 1967. "The Problem of the Rationality of Magic.” British Journal of Sociology 18 (1) April: 55-74.

https://www.researchgate.net/publication/17146314_The_Problem_of_the_Rationality_of_ Magic. https://doi.org/10.2307/588590.

Jarvie, I. C., and J. Agassi. 1970. “The Problem of the Rationality of Magic.” In Rationality: Key Concepts in The Social Sciences, edited by B. R. Wilson. Oxford: Blackwell.

Kant, I. 1783. "Beantwortung der Frage: Was ist Aufklärung?” In Immanuel Kant: Werke in zehn Bänden. Darmstadt: Wissenschaftliche Buchgesellschaft, 53-61.

Kayayan, E. 2013. "Calvin on Slavery: Providence and Social Ethics in the 16th Century." Koers: Bulletin for Christian Scholarship 78 (2): Art. \#2119, 13 pages. https://doi.org/10.4102/koers.v78i2.2119.

Keynes, J. M. 1946. "Newton, the Man.” Paper read at the tercentenary of Newton's birth, 1642. JOC/EFR March 2006. https://www-history.mcs.standrews.ac.uk/Extras/Keynes_Newton.html; https://www-history.mcs.stand.ac.uk/Extras/Keynes_Newton.html.

Latouche, S. 1995. “Avant-propos.” In L'économie devoilée, edited by S. Latouche. Paris: Editions Autrement, 15-36.

Lisapo ya Kama. (n.d.) “African History/Histoire Africaine.” Accessed August 18, 2019. http://en.lisapoyakama.org/the-moorish-civilization-when-blacks-ruled-spain/.

Locke, John. 1824. "The Works of John Locke in Nine Volumes (1824).” Accessed August 30, 2019. https://oll.libertyfund.org/titles/locke-the-works.

Lucianus. "Philosophies for Sale.” In Loeb Classical Library. Lucianus II. London, NY: Heinemann/Putnam, 448ff, specifically pp. 497ff.

Lukes, S. 1967. “The Problem of the Rationality of Magic.” British Journal of Sociology 18 (1) (April): 55-74.

https://www.researchgate.net/publication/17146314_The_Problem_of_the_Rationality_of_ Magic. https://doi.org/10.2307/588590.

Lukes, S. 1970. "Some Problems Regarding Rationality." In Rationality: Key Concepts in the Social Sciences, edited by B. R. Wilson. Oxford: Blackwell, 208-211.

Lyotard, J-F. 1977. Instructions Païennes. Paris: Galilée.

Marx, Karl. 1837. "Letter from Marx to his Father in Trier. Berlin, November 10 (1837)." First Published: Die Neue Zeit No. 1, 1897. In The First Writings of Karl Marx, edited by Paul M. Schafer. In German: Karl Marx in Seinem Briefen, edited by Saul K. Padover, translated by Paul M. Schafer. Germany: Verlag C.H. Beck. https://www.marxists.org/archive/marx/works/1837-pre/letters/37_11_10.htm. 


\section{Venter}

Mussolini, B. 1933/5. "Il dottrina del fascismo."

http://www.geocities.ws/fransavari/DottrinaFasc.pdf. Especially paragraphs II and III.

Neumann, Alexander. 2015. Après Habermas: la Théorie critique n'a pas dit son dernier mot, Paris: Delga.

Owens, C. 1987. "The Discourse of Others: Feminists and Post-modernism." In Post-modern Culture, edited by H. Foster. London: Pluto Press, 65ff.

Plato. 2002. The Republic by Plato. http://www.idph.net/conteudos/ebooks/republic.pdf.

Prothero, R. E. 1912. English Farming Past and Present. Cambridge, CUP 2013 (originally 1912.)

Ricoeur, P. 1974. "Science et Idéologie.” Revue Philosophique de Louvain1 no. 4: 328-356. https://doi.org/10.3406/phlou.1974.5792.

Riedl, M. 2012. “A Collective Messiah: Joachim of Fiore's Constitution of Future Society.” https://doi.org/10.1163/9789004339668.

Riedl, M. (Ed.). 2017. A Companion to Joachim of Fiore. https://www.academia.edu/35038681/A_Companion_to_Joachim_of_Fiore. Brill's companions to the Christian tradition. Leiden: Brill.

Taylor, K. S. 1996. "Human Society and the Global Economy." Chapter 6: Theories of Value. http://www.d.umn.edu/cla/faculty/jhamlin/4111/2111-home/value.htm.

Venter, J. J. 1981. Geloofsgebonde Denke by Anselmus: 'n Studie van sy Wysgerige Metode. Potchefstroom: PU vir CHO.

Venter, J. J. 1996. "World-picture, Individual, Society." Neohelicon 23 (1): 175-200. (Also in Proceedings of the Bi-annual Congress of SASECS Sept. 1993). Cape Town: UCT, 1994.) https://doi.org/10.1007/BF02437008.

Venter, J. J. 1997. "Mechanistic Individualism versus Organistic Totalitarianism.” International Journal for Ultimate Reality and Meaning 20 (1): 41-60. https://doi.org/10.3138/uram.20.1.41.

Venter, J. J. 1999. “"Modernity’: The Historical Ontology.” Acta Academica 31 (2): 18-46.

Venter, J. J. 2000. "Human Dignity as 'Rationality': The Development of a Conception." Analecta Husserliana 68: 129-159. https://doi.org/10.1007/978-94-011-4058-4_10.

Venter, J. J. 2001. "Early Modern Conceptions of 'Natural Law'.” Acta Academica 33 (2): 139. 


\section{Venter}

Venter, J. J. 2013. "Methodologies of Targeting: Renaissance Militarism Attacking Christianity as 'Weakness'." Koers June 2013. DOI: 10.4102/koers.v78i2.62.

https://doi.org/10.4102/koers.v78i2.62.

Voltaire. 1750. La voix du sage et du people (1750). Oeuvres complètes de Voltaire, avec préfaces, avertissements, notes, par M. Beuchot. Tome 39. Paris, Lefèvre, 1830, 340-349.

Walker, R. 2013. "Why has the History of African People been Erased?"

https://www.panafricanthought.com/video/why-europeans-erased-africans-from-history/. Clip from: Robin Walker, Siaf Miller, Saran Keita, 2013. Everyday Life in an Early West African Empire. Croydon (UK): Jacinth Martin Siven Publishing.

Wikipedia: "Great Chain of Being.” https://en.wikipedia.org/wiki/Great_chain_of_being.

Winch. P. 1964. "Understanding a Primitive Society.” In American Philosophical Quarterly 1 (4) (Oct): 307-324. Published by: University of Illinois Press on behalf of the North American Philosophical Publications. Accessed September 12, 2013. http://www.jstor.org/stable/20009143.

https://www.humannature.hps.cam.ac.uk/WeekFive1964WinchUnderstandingaprimitiveso ciety.pdf.

Winch, P. 1970. "Understanding a Primitive Society." In Rationality: Key Concepts in the Social Sciences, edited by B. R. Wilson. Oxford: Blackwell, 78-111.

Ziolo, P. 2017. (PDF Jun 29; Sep 1, 2001). "Joachim of Fiore and Apocalyptic Immanence." Accessed August 19, 2019.

https://www.researchgate.net/publication/293475126_Joachim_of_Fiore_and_apocalyptic_ immanence. 